\title{
Challenges of Economic Development in the Middle East and North Africa Region
}




\section{World Scientific Studies in International Economics}

(ISSN: 1793-3641)

Series Editor $\quad$ Robert M. Stern, University of Michigan, USA

Editorial Board Vinod K. Aggarwal, University of California-Berkeley, USA

Alan Deardorff, University of Michigan, USA

Paul DeGrauwe, Katholieke Universiteit Leuven, Belgium

Barry Eichengreen, University of California-Berkeley, USA

Mitsuhiro Fukao, Keio University, Tokyo, Japan

Robert L. Howse, University of Michigan, USA

Keith E. Maskus, University of Colorado, USA

Arvind Panagariya, Columbia University, USA

Published*

Vol. 4 The Rules of Globalization (Case Book)

edited by Rawi Abdelal (Harvard University, USA)

Vol. 5 Institutions and Gender Empowerment in the Global Economy edited by Kartik Roy (University of Queensland, Australia), Hans Blomqvist (Swedish School of Economics and Business Administration, Finland) \& Cal Clark (Auburn University, USA)

Vol. 6 Globalization and Systemic Risk edited by Douglas D. Evanoff (Federal Reserve Bank of Chicago, USA), David S. Hoelscher (International Monetary Fund, USA) \& George G. Kaufman (Loyola University Chicago, USA)

Vol. 7 Fostering Monetary and Financial Cooperation in East Asia edited by Duck-Koo Chung (North East Asia Research Foundation, South Korea) \& Barry Eichengreen (University of California, Berkeley, USA)

Vol. 8 Challenges of Economic Development in the Middle East and North Africa Region by Julia C Devlin

Vol. 9 Globalization and International Trade Policies

by Robert M Stern

Vol. 10 The First Credit Market Turmoil of the 21st Century: Implications for Public Policy edited by Douglas D Evanoff (Federal Reserve Bank of Chicago, USA), Philipp Hartmann (European Central Bank, Germany) \& George G Kaufman (Loyola University, USA)

Vol. 11 Free Trade Agreements in the Asia Pacific edited by Christopher Findlay (University of Adelaide, Australia) \& Shujiro Urata (Waseda University, Japan)

*The complete list of the published volumes in the series, can also be found at http://www.worldscibooks.com/series/wssie_series.shtml 
World Scientific

Studies in

International

Economics
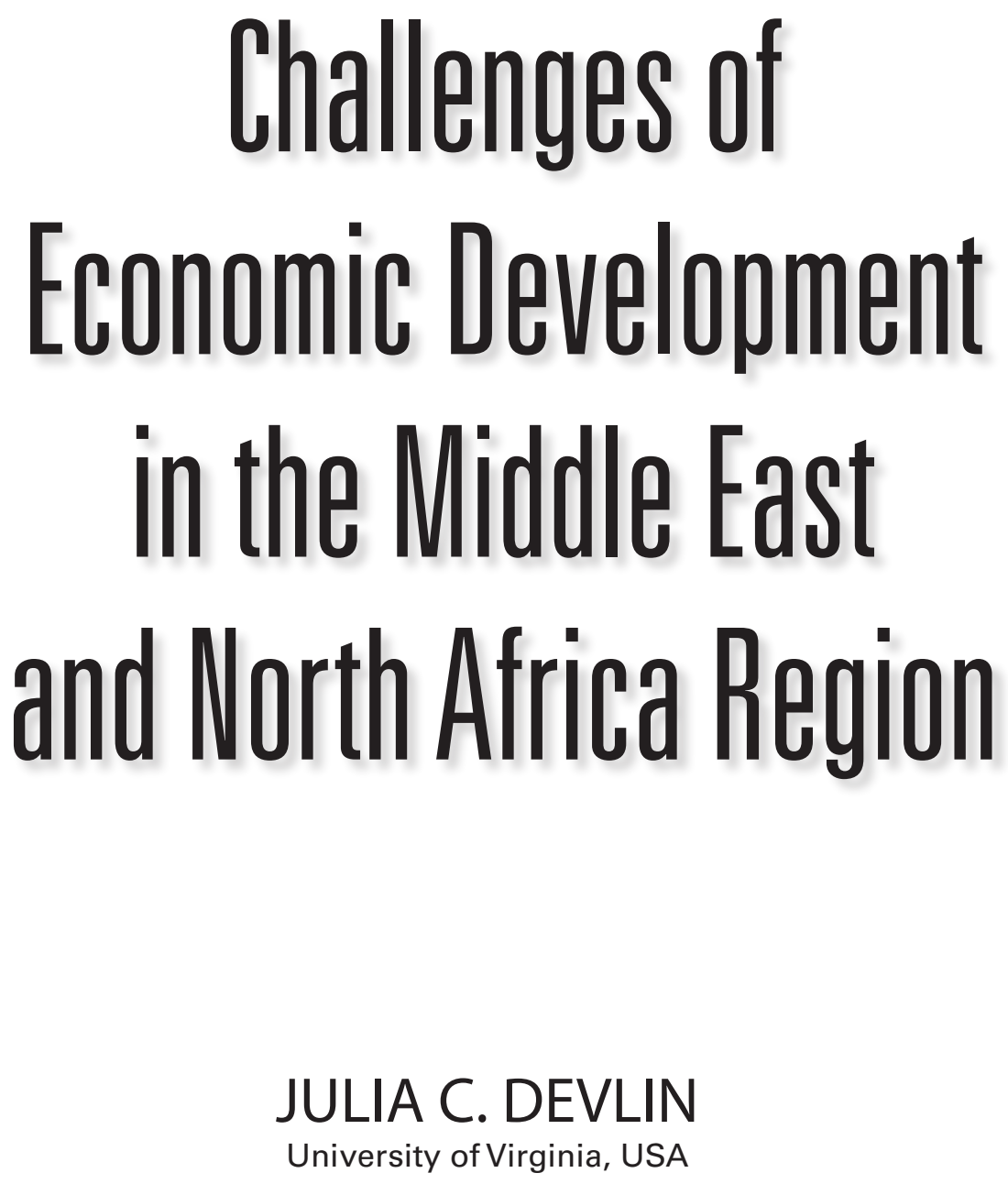

$\|$ World Scientific 
Published by

World Scientific Publishing Co. Pte. Ltd.

5 Toh Tuck Link, Singapore 596224

USA office: 27 Warren Street, Suite 401-402, Hackensack, NJ 07601

UK office: 57 Shelton Street, Covent Garden, London WC2H 9HE

\section{British Library Cataloguing-in-Publication Data}

A catalogue record for this book is available from the British Library.

\section{CHALLENGES OF ECONOMIC DEVELOPMENT IN THE MIDDLE EAST AND NORTH AFRICA REGION World Scientific Studies in International Economics — Vol. 8 \\ Copyright () 2010 by World Scientific Publishing Co. Pte. Ltd.}

All rights reserved. This book, or parts thereof, may not be reproduced in any form or by any means, electronic or mechanical, including photocopying, recording or any information storage and retrieval system now known or to be invented, without written permission from the Publisher.

For photocopying of material in this volume, please pay a copying fee through the Copyright Clearance Center, Inc., 222 Rosewood Drive, Danvers, MA 01923, USA. In this case permission to photocopy is not required from the publisher.

ISBN-13 978-981-279-344-7

ISBN-10 981-279-344-5

Typeset by Stallion Press

Email: enquiries@stallionpress.com

Printed in Singapore. 
To my parents Nora and Joseph and my sister Laura whose encouragement, love and support made this book and so much else possible. I would like to thank my Uncle Theodore for his kindness and wisdom which has guided and inspired me. To my colleagues and friends, thank you for your patience and generous insights. Finally, I would like to thank and acknowledge all my students, past, present and future, whose perpetual enthusiasm and bright interest continue to inspire me. 
This page intentionally left blank 


\section{Contents}

$\begin{array}{ll}\text { Introduction } & 1\end{array}$

$\begin{array}{ll}\text { Chapter One } & \text { Is MENA Exceptional? }\end{array}$

Chapter Two State Formation, Consolidation, and 39

Development, 1960s-1980s

Chapter Three Toward Greater Use of Markets and

83 the Global Economy?

Chapter Four Oil, OPEC, and the Challenges of Surplus Management

Chapter Five Water Scarcity and Agricultural Policy in the MENA Region

Chapter Six Building a New Future: Development in the Post-Conflict Context and Post-Disaster Recovery

Chapter Seven Is the MENA Region “Open” for Business?

Chapter Eight Making Global Integration Work for MENA Countries 
Chapter Nine Are Market Disciplines Sufficient? Industrial Policy and Technology Transfer

Chapter Ten The Keys to the Future: Human Capita 361 Development in the MENA Region

Chapter Eleven Are MENA's Labor Markets the Key 401 to Growth?

Chapter Twelve Closing the Poverty Gap in MENA

Chapter Thirteen Development Assistance and Its 473 Effectiveness in MENA Countries

Chapter Fourteen Pathways to Future Prosperity

Index 